\title{
Group Reality Therapy untuk mereduksi kecemasan narapidana wanita dalam menghadapi respon sosial menjelang masa pembebasan bersyarat
}

$\Phi$ PROCEDIA Studi Kasus dan Intervensi Psikologi p-ISSN 2302-1462; e-ISSN 2722-7669 ejournal.umm.ac.id/index.php/procedia 2021, Vol 9(3):94-99

DOl:10.22219/procedia.v9i3.16321

(c) The Author(s) 2021

()ㅇ(3) 4.0 International license

\author{
Hanum Nindialoka ${ }^{1}$
}

\begin{abstract}
Prisoners when facing the period of parole are certain to experience anxiety problems because of the negative stigma and social responses. The purpose of this case study is to reduce the prisoners's anxiety symptoms by using Group Reality Therapy. The assessment method uses semi-structured interviews, observation, and the TMAS (Talyor Manifest Anxiety Scale) scale. The subjects were four inmates, male aged 22-23 years. The results of the assessment showed that the anxiety problems experienced by the subjects were at a moderate level of anxiety. Analysis by comparing before and after psychological intervention. The results of psychological intervention using Group Reality Therapy showed a decrease in anxiety symptoms.
\end{abstract}

\section{Keywords}

Group reality therapy, anxiety, woman prisoners, social respon

\section{Pendahuluan}

Hukuman penjara merupakan sanksi berat yang harus diterima oleh orang-orang yang telah terbukti melanggar hukum dan undang-undang yang telah ditetapkan oleh Negara (Armour, 2012). Selama menjalani masa hukuman, warga binaan pemasyarakatan (WBP) akan dibina dan diberdayakan di dalam sebuah lembaga pemasyarakatan. Program pembinaan yang dilakukan oleh pihak lapas memiliki tujuan untuk membentuk kembali kepribadian para WBP menjadi individu yang patuh terhadap hukum dan tidak mengulangi perilaku melanggar hukum seperti yang pernah dilakukannya. Program pembinaan yang dilakukan di Lapas klas IIA Malang saat ini berfokus pada pembinaan mental, kerohanian dan pembinaan keterampilan kerja yang bertujuan agar para WBP nantinya setelah bebas akan memiliki kemampuan khusus untuk bekerja.

Meski telah dibekali kemampuan khusus untuk bekerja selama pembinaan, perkara akan bebas dan menghadapi lingkungan baru bukanlah hal yang mudah bagi WBP. Kecemasan merupakan salah satu permasalahan yang dihadapi oleh subjek pemasyarakatan yang mendekati masa pembebasan (Western, 2014; Schnittker et al., 2012; Shinkfield \& Graffam, 2010). Tidak hanya menjelang masa bebas, kecemasan bahkan telah terjadi sejak WBP masih awal berstatus sebagai narapidana (Patandean, 2017). Para calon mantan narapidana merasa takut akan banyak hal, mereka merasa tidak memiliki apapun dan tidak layak untuk kembali ke masyarakat, mereka merasa banyak hal yang tidak mereka ketahui tentang dunia luar karena mereka terbiasa hidup di dalam penjara (Chikadzi, 2017). Hal ini ditunjang dengan tinjauan secara psikologis menurut Karotono (2009) yang menyatakan bahwa isolasi yang lama karena disekap dalam penjara akan menyebabkan narapidana tidak memiliki partisipasi sosial, terkucilkan dan lekat dengan stigma-stigma negatif yang berkembang dalam masyarakat.

Tidak bisa dipungkiri bahwa stigma narapidana sebagai "sampah masyarakat" masih terus berkembang di lingkungan masyarakat kita hingga saat ini. Hal inilah yang secara nyata menimbulkan kecemasan pada WBP yang saat ini sudah mendekati masa pembebasan bersyarat. Kebanyakan dari WBP mengaku bahwa mereka merasa cemas untuk kembali terjun dalam kehidupan bermasyarakat. Mereka tidak yakin bahwa lingkungan akan bisa menerima keberadaan mereka kembali seperti dahulu. Tidak hanya itu, WBP juga mengalami kecemasan ketika memikirkan tentang apa yang akan mereka lakukan setelah nanti bebas dari penjara, mereka memiliki pikiran tentang kesulitan yang akan mereka hadapi untuk mencari pekerjaan karena menyandang status sebagai mantan napi.

Rasa cemas merupakan respon alami dari diri yang termasuk dalam mekanisme pertahanan diri kita. Rasa cemas mampu membantu indvidu untuk lebih waspada

${ }^{1}$ Universitas Muhammadiyah Malang,Indonesia

Korespondensi:

Hanum Nindialoka, Direktorat Program Pascasarjana, Universitas Muhammadiyah Malang, Jl. Tlogomas 246 Malang, Indonesia

Email: hanumnumnum@gmail.com 
dengan memiliki perencanaan untuk menghadapi berbagai situasi kedepannya. Namun, kecemasan akan bisa menjadi abnormal apabila direspon melebihi proporsi ancaman yang datang, atau muncul tanpa adanya stimulus yang nyata, yang dalam tingkat ekstrem akan mengganggu fungsi hidup sehari-hari (Nevid et al., 2003). Penanganan yang bisa diupayakan untuk menangani kecemasan menghadapi masa pembebasan yang dirasakan oleh WBP salah satunya ialah dengan memberikan dukungan sosial. Bentuk dukungan sosial sebagai salah satu pilihan dalam menanggulangi masalah psikologis dapat diperoleh melalui terapi kelompok. Terapi dengan metode kelompok memberikan solusi yang nyata berupa masukan dari orang lain sesama anggota kelompok yang memiliki kondisi yang serupa (Dadashazar, 2017). Pemberian terapi kelompok bagi subjek pemasyarakatan akan memberikan kesempatan bagi subjek untuk saling berbagi tentang masalah yang dihadapinya. Masing-masing subjek bisa mendapatkan solusi nyata dari subjek lainnya yang mungkin memiliki masalah yang sama dengan dirinya dan telah memecahkan masalah tersebut.

Pendekatan dalam pelaksanaan terapi kelompok yang akan diberikan kepada subjek pemasyarakatan adalah pendekatan realita. Terapi realita merupakan proses intervensi yang menekankan pada kondisi saat ini, fokus pada kekuatan pribadi, dan mendorong individu untuk mengembangkan tingkah laku yang lebih realistis sebagai bentuk dari tanggung jawab terhadap pilihan yang dilakukan agar dapat mencapai kesuksesan (Corey, 2013). Tidak ada yang lebih berperan dalam hidup seseorang melebihi pilihan hidupnya sendiri.

\section{Metode Asesmen}

Metode Asesmen yang digunakan dalam kasus ini diantaranya ialah wawancara semi terstruktur yang dilakukan dengan tujuan untuk eksplorasi informasi tentang permasalahan yang saat ini dirasakan oleh subjek. Metode yang kedua ialah dengan melakukan observasi sebagai penunjang hasil wawancara. Observasi dilakukan pada saat sesi terapi dimulai, ini bertujuan untuk mengetahu perilaku yang muncul pada masing-masing subjek pada situasi tertentu selama berjalannya terapi. Metode selanjutnya ialah pemberian Taylor Manifest Anxiety Scale (TMAS) untuk mengetahui tingkat kecemasan yang sedang dialami oleh para subjek apakah berada pada level rendah sedang atau tinggi. Pemberian skala ini juga ditujukan untuk mengetahui gejala-gejala kecemasan yang sedang dialami oleh masing-masing subjek dalam kelompok.

\section{Presentasi Kasus}

Subjek berjumlah 4 orang dengan jenis kelamin perempuan yang berusia rata-rata 22-23 tahun yang berstatus narapidana. Subjek berasal dari blok yang sama dengan pelangaran kasus penyalahgunaan narkotika. Subjek saat ini sudah menjalani $2 / 3$ masa tahanannya dan sudah mengurus proses pembebasan bersyarat.Hasil dari wawancara semi terstruktur yang telah dilakukan menunjukkan bahwa semua subjek memiliki keluhan yang secara garis besar memiliki keseragaman. Hal yang menjadi keluhan para subjek diantaranya ialah kecemasan akan respon orang-orang disekitar lingkungan tinggalnya nanti saat subjek kembali kerumah.

Subjek 1 mengaku bahwa menjelang masa pembebasannya dirinya merasakan perasaan senang namun juga merasa cemas. Kecemasan ini datang dari kekhawatirannya akan adanya omongan dari para tetangga yang tidak mengenakkan hatinya karena ia merupakan mantan napi dengan kasus penyalahgunaan narkotika. Ia juga khawatir tentang bagaimana nanti keluarga, terutama saudara-saudaranya akan memiliki anggapan yang buruk terhadapnya. Ia menganggap bahwa yang bisa dilakukannya setelah keluar dari penjara ialah kembali ke tempat tinggalnya, namun dengan riwayat kejahatannya, ia merasa pasti akan ada perubahan sikap yang ia alami dari keluarga dan lingkungannya.

Menurut keterangan subjek 1, setiap malam ia selalu tidur lebih larut daripada WBP yang lainnya. Hal ini terjadi karena subjek merasa terus kepikiran tentang bagaimana nantinya ia harus bersikap ketika pulang kembali kerumahnya. Selain rasa malu yang ia rasakan sendiri, subjek juga mengkhawatirkan nasib kedua orang tuanya yang juga pasti akan semakin malu pada tetangga dengan kepulangannya kembali. Berdasarkan hasil asesmen TMAS, subjek 1 mengalami kecemasan yang berada pada level sedang. Subjek menunjukkan gejala-gejala kecemasan diantaranya ialah kehilangan nafsu makan, sulit tidur, dihantui oleh firasat yang buruk dan sering menangis saat malam hari.

Subjek 2 merupakan WBP yang melakukan pelanggaran hukum yakni konsumsi sabu-sabu. Subjek merupakan seorang residivis yang sebelumnya sudah pernah ditahan atas kasus yang sama. Hasil asesmen TMAS menunjukkan bahwa tingkat kecemasan subjek 2 berada pada level sedang. Subjek 2 mengutarakan bahwa sebagai residivis hal yang paling ia cemaskan adalah bukan tentang omongan orang luar namun lebih kepada respon yang ia dapatkan dari keluarga suaminya. Ia juga mengkhawatirkan kalau anaknya sudah tidak mau lagi tinggal dengannya karena mungkin merasa malu. Selama menjalani masa hukumannya yang kedua ini subjek sama sekali tidak pernah mendapatkan kunjungan dari anak-anaknya. Suami subjek mengatakan bahwa anak-anak sedang sibuk bekerja sehingga tidak bisa mengunjunginya, namun subjek tetap merasa cemas dengan sikap anaknya yang terkesan enggan untuk bertemu lagi dengannya

Subjek 3 juga merupakan WBP dengan kasus kriminal penyalahgunaan narkotika namun ia terkena pasal berlapis yakni dengan penjualan narkotika. Berdasarkan hasil skrining TMAS subjek 3 memiliki tingkat kecemasan yang berada pada level rendah. Subjek melaporkan bahwa dirinya mengalami perasaan cemas dan bingung tentang 
apa yang akan dilakukannya setelah bebas dari penjara. Subjek 3 merasa cemas jika dirinya akan sangat sulit mencari pekerjaan dimana-mana karena pernah memiliki catatan kriminal. Subjek 3 megatakan bahwa ia harus memiliki penghasilan sendiri untuk menghidupi dirinya dan anaknya yang sekarang sedang dititipkan kepada orang tuanya. Subjek 3 telah mengalami konflik yang panjang hingga pisah ranjang dengan suaminya semenjak sebelum ia ditangkap. Subjek 3 merasa bahwa kehidupan diluar penjara yang akan ia hadapi sebentar lagi nampak akan lebih sulit karena ia harus menanggung sangsi sosial.

Tidak jauh berbeda dengan ketiga subjek yang lainnya subjek 4 memiliki tingkat kecemasan yang berada pada level sedang. Subjek 4 merupakan WBP dengan kasus narkotika yang memiliki kecemasan dan kekhawatiran tentang bagaimana nanti ia akan keluar dan mendapatkan pekerjaan. Sebelum ditangkap subjek 4 bekerja di dunia malam sebagai Ladies Company. Subjek mengaku bahwa nanti ketika ia keluar, teman-temannya yang dahulu pasti akan kembali mengajaknya bekerja kembali di dunia malam dan ia merasa khawatir akan kembali terlibat dengan narkotika.

Secara garis besar keempat subjek memiliki keluhan yang sama yakni mencemaskan bagaimana lingkungannya akan menerima mereka setelah mereka keluar dari tahanan. Berkaitan dengan fenomena ini, pendekatan berbasis realitas yang dikemukakan oleh William Glasser berpandangan bahwa setiap individu yang dilahirkan ke dunia memiliki lima kebutuhan mendasar yang harus terpenuhi jika ingin merasa bahagia dalam hidupnya. Kebutuhan tersebut diantaranya yakni kebutuhan untuk bertahan hidup, dicintai, kekuatan, kesenangan dan kebebasan. Adanya ketidak bahagiaan dapat disebabkan karena adanya salah satu dari kelima kebutuhan dasar tersebut yang tidak terpenuhi (Corey, 2008). Kebutuhan akan cinta menurut Glasser (2005) merupakan satu kebutuhan yang paling utama dari seorang individu karena sebagai makhluk sosial, untuk memenuhi kebutuhan yang lainnya kita memerlukan orang lain. Kebutuhan akan cinta tidak hanya terfokus pada terjalinnya relasi romantis saja. Lebih daripada itu konstrak cinta menurut Glasser mencangkup adanya penerimaan dari orang-orang terdekat seperti keluarga, teman, pasangan, kolega, tetangga, kelompok hobi, dan lain sebagainya.

Sebagai seorang narapidana yang telah menjalani hukumannya selama bertahun-bertahun terkurung dalam penjara para narapidana yang sudah mendekati masa pembebasan pasti akan merasakan khawatir tentang kehidupan selanjutnya saat mereka harus kembali ke lingkungan sosial. Keempat subjek pada kasus ini juga mengatakan bahwa kekhawatiran yang mereka rasakan saat ini yang paling besar adalah bagaimana menghadapi sangsi sosial ketika mereka kembali ke masyarakat. Keempat subjek ini mengatakan bahwa mereka banyak mendapatkan cerita dari para residivis tentang stigma negatif dari lingkungan masyarakat yang akan mereka terima. Adanya stigma negatif ini tidak hanya berpengaruh pada kualitas hubungan sosial subjek, namun juga berimbas pada bagaimana subjek akan mendapatkan kepercayaan lagi untuk bisa bekerja dan menghidupi dirinya dengan cara yang baik. Dalam hal ini kebutuhan dasar untuk bertahan hidup (survival) akan terasa sulit untuk terpenuhi karena adanya krisis kepercayaan dari masyarakat yang mereka terima.

Berdasarkan hasil dari uraian masalah yang muncul pada setiap individu, sasaran intervensi yang akan dilakukan akan terfokus pada bagaimana cara merduksi kecemasan yang dirasakan oleh subjek dengan membuat subjek lebih menyadari bahwa dirinya memiliki kontrol penuh atas apa yang akan ia lakukan untuk menjalani masa depan yang lebih baik sesuai dengan ekspektasinya.

\section{Diagnosis dan Prognosis}

Berdasarkan uraian kasus, hasil asesmen dan rujukan dari Diagnostic and Statistical Manual of Mental Disorder Fifth Edition (DSM-V) (APA, 2013), maka dapat ditegakkn diagnosis bahwa subjek secara penuh memenuhi kriteria diagnostik problem kode V62.5 (Z65.2) Problem Related to Release from Prison. Masalah yang dimaksud disini ialah kecemasan yang dihadapi subjek tentang bagaimana respon sosial yang akan diterimanya pasca subjek bebas dari penjara.

Adapun prognosis pada subjek dapat diperkirakan keberhasilan dari intervensi yang akan diberikan berpengaruh baik. Hal tersebut melihat motivasi yang dimiliki oleh para subjek dalam seting kelompok ini cukup besar ketika akan diberikan intervensi. Selain itu, para subjek juga cukup kooperatif dalam proses asesmen sehingga hal tersebut juga dapat bertahan hingga proses intervensi berakhir.

\section{Intervensi}

Intervensi yang digunakan dalam kasus ini ialah terapi realita dalam seting kelompok. Pemberian terapi realita dalam seting kelompok diketahui secara signifikan dapat menurunkan tingkat stress, kecemasan, dan depresi (Farmani et al., 2015)(Farmani, Taghavi, Fatemi, \& Safavi, 2015). Metode WDEP (wants, doing, evaluation, planning) yang digunakan dalam terapi realita akan dilakukan dalam seting kelompok.

Intervensi dengan metode ini dilakukan untuk membimbing subjek agar menemukan cara yang lebih efektif dalam mengatasi kecemasan yang mereka rasakan terkait dengan berbagai hal yang akan mereka hadapi setelah bebas dari tahanan. Subjek juga diharapkan akan memiliki kontrol yang baik dan lebih efektif atas kehidupan mereka di masa yang akan datang.

Pelaksanaan terapi kelompok pada subjek pemasyarakatan memiliki beberapa keunggulan. Keunggulan yang pertama ialah memberikan kesempatan bagi subjek untuk saling bertukar pengalaman dengan teman di dalam kelompok sehingga akan melahirkan 
berbagai solusi yang bisa untuk dijadikan pertimbangan dalam pemecahan masalah. Keunggulan yang kedua ialah dengan terjalinnya komunikasi dan keintiman antar anggota kelompok proses eksplorasi masalah akan lebih memiliki nilai terapeutik karena setidaknya subjek telah meluapkan perasaan dan pikirannya kepada anggota kelompok. Selain itu terapi yang dilakukan dengan metode berkelompok telah terbukti secara ilmiah dapat menurunkan tingkat kecemasan pada narapidana (Gharavi et al., 2015). Terapi realita dalam seting kelompok ini di rancang selama 6 sesi :

Sesi I: Penjelasan kontrak kerja. Terapis menjalin raport dan memperkenalkan program terapi yang akan dilakukan serta menjelaskan aturan-aturan dalam kelompok, yaitu terapis mendorong kelompok untuk saling terbuka dan adanya kerahasiaan dalam terapi dan diskusi kelompok. Selanjutnya setiap anggota kelompok saling memperkenalkan diri. Dilanjutkan dengan pemberian skala kecemasan TMAS sebagai pretest. Pada sesi ini keseluruhan subjek memperkenalkan dirinya satu-persatu. Sesi ini berjalan lancar, seru dan tanpa malu-malu anggota kelompok saling mengenal satu sama lainya. Saat diberikan penjelasan tentang aturan kelompok keseluruhan subjek memahaminya dengan baik. Hasil skala kecemasan yang diberikan menunjukkan bahwa ada tiga orang yang memiliki kecemasan dalam kategori sedang sementara satu orang berada pada kategori rendah

Eksplorasi keinginan, kebutuhan dan persepsi (wants). Pada sesi ini terapis menjelaskan secara verbal tentang adanya Quality of World dan Basic needs pada setiap anggota kelompok. Selanjutnya, secara bergantian subjek mengungkapkan keinginan, kebutuhan dan sejauh mana pemenuhan kebutuhan yang telah mereka upayakan. Hasil dari sesi yaitu keseluruhan subjek memiliki keinginan yang sama karena masalah yang dihadapinyapun sama dimana mereka mengalami kecemasan terkait mengahadapi respon atas stigma buruk napi dari masyarakat.

Mendiskusikan perilaku total (doing). Pada sesi ini seluruh anggota kelompok dan terapis ,mendiskusikan perilaku mereka, bagaimana pikiran perasaan,respon fisik ketika adanya perilaku yang tidak ia sukai dari orang lain. Dalam sesi ini setiap subjek menceritakan bagaimana dan apa saja yang telah mereka lakukan dan rasakan selama ini. Kesimpulan pada sesi ini bahwa mereka memiliki respon masing-masing dalam menghadapi rasa khawatirnya yakni dengan melamun, tidak makan, tidak bisa tidur dan sesekali menangis atau diam.

Sesi IV: Penilaian dan tindakan (evaluasi). Pada sesi ini semua anggota kelompok saling memeriksa keinginan dan evaluasi perilakunya selama ini. Terapis dalam sesi ini memiliki peran sebagai pengarah dan pendorong bagi subjek untuk mengevaluasi perilaku memiliki sisi postif di dalam dirinya, apakah evaluasi pikiran sekarang dapat merugikan atau tidak dan apakan yang mereka lakukan dapat membantu dirinya mencapai yang diinginkan.
Hasil pada sesi ini keseluruhan anggota kelompok dapat mengevaluasi dirinya dengan perilaku yang ia lakukan atas perilaku orang lain dan mereka saling bertukar pendapatnya serta saling mendukung satu sama lain.

Menyusun keinginan dan komitmen bersama (plan). Terapis dan anggota kelompok berupaya menyusun perencanaan terkait dengan bagaimana atau apa saja upaya yang dapat diusahakan untuk mendapatkan apa yang mereka inginkan (wants) yaitu untuk nantinya siap terjun di masyarakat sehingga dengan rencana yang matang mereka dapat mereduksi kecemasannya saat ini dan percaya atas kemampuan dalam dirinya. Target pada sesi ini ialah anggota kelompok dapat membuat strategi dengan membuat rencana dan menentukan tindakan yang realistis. Setiap anggota kelompok memiliki planning yang beragam namun dengan satu tujuan yang sama yaitu mereka dapat bergaul dengan teman-teman disekitarnya.

Evaluasi dan terminasi. Terapis melakukan evaluasi terhadap planning yang telah anggota kelompok rencanakan dengan menanyakan kesulitan dan hambatan yang dialami. Kemudian anggota kelompok diminta untuk mengungkapkan perasaannya setelah menjalankan sesi terapi dan diakhiri dengan pemberian pascates TMAS untuk mengukur adanya perubahan derajat kecemasan tiap-tiap subjek setelah melakukan seluruh rangkaian terapi.

Follow-up. Follow $U$ p akan dilakukan 2 minggu setelah terminasi dilakukan untuk mengetahui apakah terjadi perbaikan kondisi dan penurunan simtom kecemasan dari subjek. Follow-up dilakukan dengan pertemuan dan perbincangan langsung dengan subjek secara kelompok. Semua anggota kelopok beserta terapis membicarakan tentang perasaan yang dirasakan setelah sesi terapi kelompok selesai. Apakah subjek mengalami penurunan tingkat kecemasan dan apakah subjek merasa lebih baik dibandingkan kondisi sebelumnya. Pemberian TMAS juga dilakukan pada sesi ini untuk melihat apakah hasil dari intervensi yang dilakukan dapat berefek jangka panjang dan apakah ada faktor penghambat yang dialami subjek.

Hasil dari sesi ini ialah subjek merasa dirinya sudah lebih tenang dan memiliki bayangan yang terarah tentang apa yang akan mereka harus lakukan nanti paska bebas. Selain itu subjek juga mengaku bahwa kecemasannya cenderung bisa terkontrol karena subjek kekhawatiran yang subjek rasakan sudah tidak sebesar sebelumnya.

\section{Hasil dan Pembahasan}

\section{Hasil}

Hasil dari intervensi terapi realita yang diterapkan kepada keempat subjek menunjukkan adanya perubahan tingkat kecemasan yang dialami masing-masing subjek. Perubahan kondisi subjek tidak berlangsung secara langsung melainkan secara bertahap. Keempat subjek membutuhkan waktu dan dorongan untuk secara rinci mengutarakan apa yang menjadi keinginan serta harapannya kedepan, 


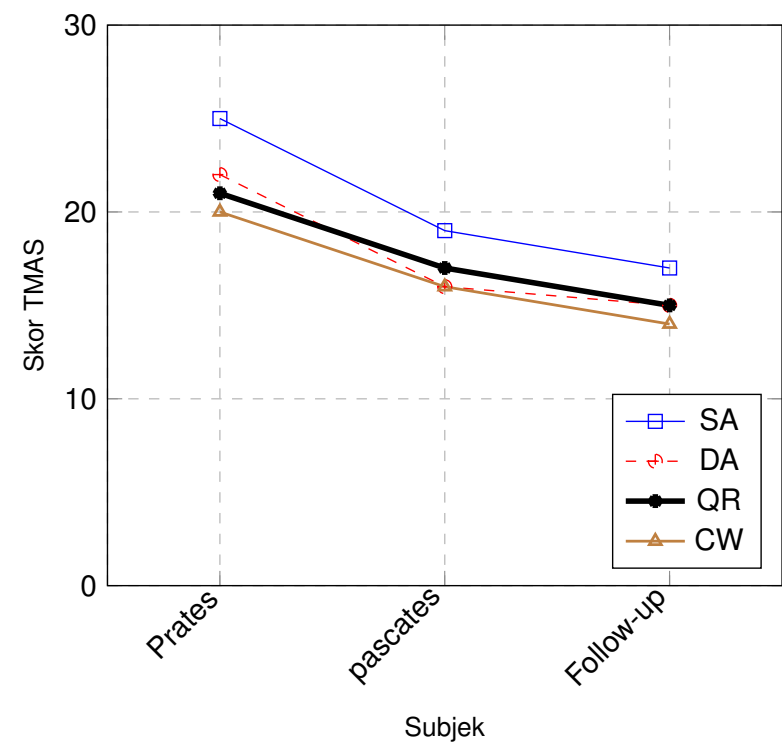

Gambar 1. Perolehan skor TMAS pada prates, pascates dan follow-up t-test TMAS.

sehingga pada sesi kedua proses intervensi dicapailah kesepakatan terkait keinginan keempat subjek yakni dapat mengatasi rasa kecemasannya untuk menghadapi respon sosial masyarakat nanti saat telah bebas.

Setelah menemukan apa yang menjadi keinginannya (wants), setiap subjek dalam kelompok melakukan diskusi dan sharing tentang bagaimana selama ini mereka menghadapi atau merespon rasa khawatirnya terkait dengan pemenuhan wants yang mereka harapkan dan kemudian melakukan evaluasi pada sesi selanjutnya. Dalam sesi ini subjek mulai mengungkapkan secara terbuka tentang apa yang mereka rasakan saat ini dan mendapatkan dukungan dari teman-temannya.

Interaksi yang positif dan saling membangun dalam kelompok ini membawa efek terapeutik bagi subjek, karena merasa didengarkan, dan merasa tidak sendirian. Proses evaluasi yang menuntut setiap anggota berperan secara aktif untuk mengeluarkan gagasan dan ide dapat menumbuhkan insight bagi subjek untuk melahirkan solusi dalam menyusun (plan) atau rencana strategi pencapaian (wants) yang dilakukan pada sesi kelima proses terapi. Selanjutnya memasuki sesi terminasi dan follow-up subjek mengkonfirmasi bahwa dengan model terapi realita kelompok yang telah dijalani dapat membantu mereka untuk secara lebih jelas dan kongkrit mengetahui apa yang harus dilakukan kedepannya dan hal ini dapat mengurangi kecemasan subjek saat ini.

Secara keseluruhan hasil kuantitatif terjadinya penurunan kecemasan yang dirasakan oleh keseluruhan subjek setelah menjalani rangkaian sesi intervensi dapat ditunjukkan oleh grafik perolehan skor prates dan pascates TMAS lebih jelasnya lihat Gambar 1 .

Skala TMAS memiliki tiga tingkatan kategori skor yang menunjukkan tinggi rendahnya derajat kecemasan yang dialami oleh seseorang. Individu yang memiliki skor $<20$ menunjukkan indikasi kecemasan dalam kategori ringan, 20-25 kategori sedang, dan $>25$ merupakan kategori berat. Berdasarkan kategori tersebut dapat diketahui dari bagan 2 bahwa secara keseluruhan keempat subjek yang mendapatkan intervensi Group Reality Therapy mengalami penurunan tingkat kecemasan dari sebelum dilakukannya intervensi (prates) dibandingkan dengan setelah dilakukkannya intervensi (pascates) dan follow-up.

Penurunan tingkat kecemasan yang dialami oleh subjek sejalan dengan hasil perubahan yang terjadi pada proses terapi yang diperkuat dengan hasil wawancara pada setiap subjek terkait dengan berkurangnya gejala-gejala kecemasan yang dirasakan. Keseluruhan subjek telah melengkapi tahapan terapi realitas, dan saat ini derajat kecemasan yang dirasakan subjek sudah berkurang.

Selain dapat lebih mengenal kekurangan dan kelebihan dirinya, metode WDEP yang dilaksanakan dalam terapi kelompok juga mengahasilkan rencana tindakan yang dapat dilakukan secara realistis oleh masing-masing dari subjek. Rencana tindakan yang telah didiskusikan bersama di dalam kelompok membuat subjek merasa lebih memiliki persiapan yang matang untuk terjun kembali ke masyarakat. Selain itu, dengan support yang terjalin antar anggota kelompok membuat subjek merasa lebih bisa menerima kenyataan bahwa setiap orang memang memiliki kekurangan dan kelebihan namun sebagai individu kita tetap memiliki kontrol penuh atas apa yang akan menjadi pilihan hidup kita kedepannya.

\section{Pembahasan}

Hasil dari intervensi menunjukkan bahwa Group Reality Therapy dapat menurunkan derajat kecemasan yang dirasakan oleh narapidana wanita dalam menghadapi respon sosial menjelang masa pembebasannya. Berdasarkan kasus yang telah diulas diatas, target perubahan dalam kasus ini telah berhasil dicapai. Hal ini ditunjukkan dengan berkurangnya skor pada Taylor Manifest Anxiety Scale (TMAS) yang berarti bahwa terdapat reduksi tingkat kecemasan yang digambarkan oleh berkurangnya simtom.

Hasil ini juga didukung oleh keterangan dari masingmasing subjek bahwa pasca menjalani rangkaian sesi intervensi ini subjek merasa bahwa dirinya menjadi lebih siap untuk kembali ke masyarakat dengan adanya planing strategi yang telah tersusun, dan kesadaran diri yang meningkat bahwa dirinya memiliki kontrol penuh atas pengambilan keputusan serta tindakan dalam menghadapi hambatan di dalam hidupnya di waktu yang akan datang. Terapi realita yang dilakukan dalam seting kelompok memang terbukti efektif untuk mengatasi berbagai masalah individu yang berkaitan dengan persoalan umum dan sulit seperti permasalahan pribadi, sosial, belajar atau akademik, serta karir (Corey, 2008).

Selain itu terapi realita dalam seting kelompok dapat membantu anggota kelompok mengekspresikan 
dirinya dengan diskusi yang santai, sehingga antar anggota kelompok dapat saling mengajarkan cara untuk menghadapi perasaan negatif dan mengontrol apa yang mereka rasakan (Farmani et al., 2015). Dalam hal ini pemberian intervensi yang diterapkan pada subjek yang akan segera bebas juga terbukti dapat membantu subjek pemasyarakatan untuk menghadapi realita kehidupan mereka di masa yang akan datang. Setiap subjek dalam kelompok telah memiliki strategi masing-masing untuk mencapai tujuan yang mereka inginkan yakni menjalani kehidupan yang lebih baik setelah bebas dari penjara.

Adanya strategi yang sudah tersusun secara realistis dapat meningkatkan fokus subjek atas pengembangan dirinya sehingga dapat mengatasi kecemasan yang dirasakannya selama ini. Semua target dalam sesi terapi yang dilaksanakan sebanyak enam kali tatap muka dengan menggunakan metode wants, doing, evaluation, dan planning (WDEP) tercapai dan memberikan perkembangan yang positif bagi subjek. Rangkaian sesi ini memberikan pemahaman pada diri subjek bahwa pilihan dan strategi yang telah ia buat akan berdampak pada perilaku dirinya dan orang lain (Nelson-Jones, 2015).

Faktor lain yang juga menjadi kontribusi dalam keberhasilan terapi ini ialah pelaksanaan terapi yang dilakukan secara berkelompok sehingga komitmen untuk selalu hadir dan terlibat dalam terapi terus terjaga. Kehadiran teman dalam proses terapi kelompok membuat massing-masing dari subjek merasakan perasaan didukung dan tidak sendiri dalam menghadapi persoalannya. Selain itu seting kelompok juga menjadikan subjek lebih memiliki responsibilitas atas kemajuan kondisi teman dalam kelompoknya, sehingga menuntun masing-masing subjek untuk dapat berperan secara lebih aktif lagi dalam kelompok. Hal ini diungkapkan oleh Corey (2013) bahwa setiap anggota dalam kelompok dapat menjadi perangsang untuk komitmen pada hasil yang telah disepakati

\section{Simpulan}

Terapi realita kelompok dapat menurunkan kecemasan pada narapidana yang merasa cemas atas respon sosial menjelang masa pembebasan bersyarat. Penurunan derajat kecemasan yang dialami oleh narapidana ditandai dengan menurunnya perolehan skor dari Taylor Manifest Anxiety Scale (TMAS) dan berkurangnya simtom kecemasan berupa perilaku yang tampak seperti subjek tidak lagi merasa sulit untuk tidur di malam hari, kualitas tidur subjek lebih baik daripada sebelumnya dan meningkatnya minat dalam melakukan aktivitas sehari-hari.

Perubahan perilaku yang nampak pada subjek diakibatkan oleh karena dukungan dari anggota kelompok dan tersusunnya planing strategi yang realistis oleh masingmasing subjek untuk mencapai tujuan hidupnya. Hal ini juga membuat subjek mampu mengelola rasa cemasnya karena subjek merasa lebih siap untuk menjalani kehidupannya di masa yang akan datang.

\section{Referensi}

Armour, C. (2012). Mental Health in Prison: A Trauma Perspective on Importation and Deprivation. International Journal of Criminology and Sociological Theory, Vol. 5, No.2, 886-894. https://ijcst.journals.yorku.ca/index.php/ ijcst/article/view/35703/32435

Chikadzi, V. (2017). Challenges Facing Ex-Offenders When Reintegrating Into Mainstream Society in Gauteng, South Africa. Social Work/Maatskaplike Werk, Vol. 53 No. 2 Issue 8. http://dx.doi.org/10.15270/52-2-569

Corey, G. (2008). Teori dan Praktek Terapi dan Psikoterapi. Rafika Aditama.

Corey, G. (2013). Teori dan praktek terapi dan psikoterapi. Refika aditama

Dadashazar, N. (2017). Offender Recidivism: A Quantitative Study of Motivational Risk Factors and Counseling. Walden University ScholarWorks.

Farmani, F., Taghavi, H., Fatemi, A., \& Safavi, S. (2015). The Efficacy of Group Reality Therapy on Reducing Stress, Anxiety and Depression in Patients with Multiple Sclerosis (MS). Behavioral Research Center of SBMU

Gharavi, M. M., Kashani, H., Lotfi, M., \& Borhani, M. (2015). Comparison of Depression, Anxiety, General Mental Health and Self-Esteem Among Prisoners in Consultancy and Ordinary Wings. Journal of Fundamentals of Mental Health, Vol 17 (1), 7-52. http://jfmh.mums.ac.ir/article_3799.html

Glasser, W. (2005). New Vision for Counseling. The Family Journal : Counseling and Therapy for Couples and Families, 12 No.4, 339-341. https://doi.org/10.1177/1066480704267486

Karotono, K. (2009). Patologi Sosial: Jilid I. Raja Grafindo.

Nelson-Jones, R. (2015). Teori dan Praktik Terapi dan Terapi. Pustaka Pelajar

Nevid, S., Rathus, A., \& Greene, B. (2003). Psikologi Abnormal: Edisi Kelima Jilid 1. Erlangga.

Patandean, S. T. (2017). Efektivitas Cognitive Behaviour Therapy untuk Menurunkan Kecemasan Narapidana Menjelang Bebas di Lapas Kelas II A Pamekasan. Tesis Fakultas Psikologi Universitas Airlangga.

Schnittker, J., Massoglia, M., \& Uggen, C. (2012). Out and Down: Incercaration and Psychiatric Disorders. Journal of Health and Social Behaviour,53 (4), 448-464. https://doi.org/ $10.1177 / 0022146512453928$

Shinkfield, A., \& Graffam, J. (2010).The Relationship Between Emotional State and Success in Community Reintegration for Ex-Prisoners. International Journal of Offender Therapy and Comparative Criminology, 54 No. 3, 346-360. https: //doi.org/10.1177/0306624X09331443

Western, B., Braga, A., Davis, J \& Sirois, C. (2014). Stress and Hardship After Prison. Department of Sociology. 